\title{
KAPASITAS PENANGKAPAN PUKAT CINCIN MINI DI PEMALANG
}

\author{
Erfind Nurdin dan Tri Wahyu Budiarti \\ Peneliti pada Balai Riset Perikanan Laut, Muara Baru-Jakarta \\ Teregistrasi I tanggal: 15 Oktober 2008; Diterima setelah perbaikan tanggal: 21 Januari 2009; \\ Disetujui terbit tanggal: 13 April 2009
}

\begin{abstract}
ABSTRAK
Sumber daya ikan pelagis kecil di Laut Jawa merupakan komoditi perikanan yang penting dan bersifat strategis. Sejalan dengan perkembangan pemanfaatannya, tekanan penangkapan yang tinggi dialami oleh hampir seluruh kawasan, terlebih di wilayah tradisionil. Kapasitas penangkapan akhir-akhir ini menjadi isu penting dalam perikanan global, mengingat di berbagai kawasan terjadi kapasitas berlebih dan penurunan stok ikan. Salah satu cara untuk mengetahui status perikanan terkini dilakukan dengan mengukur kapasitas perikanan. Penelitian ini dilakukan pada bulan Mei dan Juli tahun 2007 dengan metode Data Envelopment Analysis. Nilai rata-rata pemanfaatan variabel input (VIU) untuk daya lampu dan bahan bakar menunjukkan nilai di atas 1 (optimum = 1) yang mengindikasikan adanya kelebihan penggunaan variabel sehingga dipandang perlu untuk melakukan pengurangan variabel input. Nilai pemanfaatan kapasitas (CU) lebih besar dari 0,5 hampir mencapai $60 \%$ dari 106 kapal contoh. Hal ini menunjukkan bahwa nilai CU kurang dari 1 mendominansi distribusi perolehan nilai CU yang dapat diartikan telah terjadi kelebihan kapasitas pemanfaatan untuk penangkapan pukat cincin mini dengan basis di Pemalang, sehingga perlu upaya pengurangan kapasitas.
\end{abstract}

KATAKUNCI: data envelopment analysis, pukat cincin mini, kapasitas penangkapan, Pemalang

\section{ABSTRACT: Fishing capacity of mini purse seine in Pemalang. By: Erfind Nurdin and Tri Wahyu Budiarti}

Small pelagic fish resource in Java sea is an important fishery commodity. Nowadays high fishing pressure is experienced by mostly fishing areas, particularly in traditional zone. Fishing capacity recently becomes important issue in global fishery, because over capacity and fish stock decreasing is occured in various areas. One method to know the fishery status is by measuring fishery capacity, which is categorized as over capacity, under capacity or optimal condition. This study was carried out on May and July 2007. The method applied in this measurement of fishing capacity was DEA method (Data Envelopment Analysis). The average of variable input utilization for light intensity and fuel showed value of more than 1 (optimum =1), indicating the usage of excess variable that need to reduce the input variable. The value of higher than 0.5 of capacity utilization showed $60 \%$ from 106 ships sample. This indicates that the $C U$ value of less than 1 dominated the distribution of capacity utilization value. For mini purse seine based in Pemalang showed over capacity. This means, it needs to reduce the effort of fishing capacity.

\section{KEYWORDS: data envelopment analysis, mini purse seine, fishing capacity, Pemalang}

\section{PENDAHULUAN}

Pemanfaatan sumber daya ikan di beberapa wilayah perairan Indonesia khususnya di pantai timur Sumatera dan utara Jawa ditengarai sudah melampaui batas penangkapan maksimum dan cenderung terjadi lebih tangkap. Produktivitas penangkapan ikan menurun sehingga berdampak pada peningkatan kemiskinan masyarakat nelayan skala kecil. Hal ini menjadi jelas bahwa pengurangan kelebihan kapasitas penangkapan ikan menjadi aksi yang mendasar guna menjamin keberlanjutan kegiatan penangkapan ikan dan perekonomian nelayan (Wiyono \& Wahju, 2006).

Diduga struktur perikanan pukat cincin di Laut Jawa telah berubah terutama untuk nelayan skala kecil.
Banyak pelaku usaha perikanan pukat cincin yang merubah usahanya ke jenis perikanan lain atau tetap bertahan dengan cara melakukan berbagai efisiensi. Hal ini dilakukan karena jumlah hasil tangkapan yang kurang baik dan daerah penangkapan yang semakin jauh serta biaya operasional yang ditanggung semakin melonjak. Beberapa upaya dilakukan oleh nelayan agar tetap eksis di bidang usaha penangkapan dengan pukat cincin di Laut Jawa, antara lain modifikasi sistem maupun teknik penangkapan, pemilihan daerah penangkapan yang efektif, pengurangan jumlah trip saat musim paceklik dan pengurangan jumlah armada untuk mencapai efisiensi penangkapan.

Perkembangan perikanan global akhir-akhir ini ditandai dengan terjadinya kapasitas berlebih (over

Korespondensi penulis:

JI.Muara Baru Ujung, Kompleks Pelabuhan Perikanan Samudera-Jakarta 1440, E-mail: kanlutmb@indosat.net.id 
capacity) di berbagai kawasan dunia untuk berbagai jenis ikan. Kelebihan jumlah kapal berakibat pada menurunnya stok ikan dan lebih tangkap. Sekitar $50 \%$ stok ikan dunia telah dimanfaatkan secara penuh (fully exploited), sehingga tidak ada ruang untuk pengembangannya (Sularso, 2005).

Penurunan kelimpahan stok ikan pelagis kecil dan bertambahnya jumlah para pelaku usaha baru penangkapan ikan menggunakan pukat cincin mengakibatkan turunnya produktivitas per upaya. Tata laksana perikanan bertanggungjawab (Code of Conduct for Responsible Fisheries) mengajak kepada seluruh negara untuk menghindari penangkapan berlebih dan kelebihan kapasitas penangkapan ikan agar keberlanjutan penangkapan ikan dapat terjamin (FAO, 1995).

Atmadja (2002) mengatakan bahwa perubahan taktik penangkapan dari armada pukat cincin telah memberikan kontribusi terhadap meningkatnya efisiensi penangkapan. Penelitian ini bertujuan untuk mengkaji kapasitas penangkapan dan efisiensi teknis perikanan pukat cincin mini (mini purse seine) di Pemalang, Jawa Tengah. Diharapkan hasil penelitian ini dapat memberikan informasi dan masukkan mengenai kontrol operasi penangkapan secara efektif dalam penerapan regulasi yang ketat oleh pemerintah.

\section{BAHAN DAN METODE}

\section{Pengumpulan Data}

Data yang digunakan bersumber dari laporan kegiatan pendaratan ikan harian (tahun 2006-2007) di tempat pendaratan ikan Tanjung Sari yang merupakan basis pendaratan kapal purse seine mini di Pemalang, Jawa Tengah dengan menggunakan bantuan tenaga lapangan (enumerator). Pada tanggal 3-19 Mei 2007 dan 16-23 Juli 2007 dilakukan survei langsung lapangan oleh peneliti.

Data harian hasil tangkapan ikan dari pukat cincin mini yang tercatat di tempat pendaratan ikan tahun 2006-2007, diolah untuk mendapatkan data pada level bulanan atas output (hasil tangkapan) dan upaya penangkapan ikan.

Ada 106 buah kapal digunakan sebagai contoh untuk mengukur dan membandingkan kapasitas penangkapan (capacity utilization) tiap kapal. Input tetap yang digunakan ada 4 jenis, terdiri atas gross tonage, panjang kapal, kekuatan mesin, dan panjang jaring. Sedangkan pemanfaatan variabel input (variable input utilization) terdiri atas daya lampu (variable input utilization 1), bahan bakar (variable input utilization
2), dan perbekalan (variable input utilization 3). Variabel output-nya adalah total hasil tangkapan karena tidak semua hasil tangkapan memberikan kontribusi terus-menerus.

\section{Analisis Data}

\section{a. Pra-Analisis Data}

Data kapal yang digunakan sebagai input data dibedakan menjadi 2, yaitu input tetap (fixed input) dan inputyang berubah (variable input). Sebagai input tetap adalah gross tonage, panjang kapal $(\mathrm{m})$ dan kekuatan kapal (HP), $\left(\mathrm{X}_{\mathrm{f}, \mathrm{n}}\right)$. Selanjutnya, faktor-faktor lain yang bersifat tidak tetap, seperti jumlah anak buah kapal (orang), penggunaan bahan bakar minyak (liter), jumlah trip (jumlah tawur) ditetapkan sebagai input yang berubah $\left(\mathrm{X}_{\mathrm{v}, \mathrm{n}}\right)$. Jumlah total hasil tangkapan $m$ oleh alat tangkap $j\left(U_{j m}\right)$ ditetapkan sebagai output data.

\section{b. Analisis Data}

Dengan metode pengukuran output-oriented, efisiensi teknis ditentukan sebagai maksimum penambahan output yang dimungkinkan tanpa perubahan faktor tetap (fixed factors) produksi. Sedangkan, kapasitas penangkapan didefinisikan sebagai kemampuan industri penangkapan ikan untuk menghasilkan output potensial.

Dalam kajian ini, efisiensi teknis dan kapasitas pemanfaatan (capacity utilization) suatu alat tangkap dianalisis dengan menggunakan data envelopment analysis, yaitu suatu pendekatan matematika atau pemrograman linear.

1. Pertama, hasil tangkapan kita tentukan sebagai vektor output, $u$ dan daya lampu, bahan bakar dan perbekalan sebagai vektor input, $x$. Sehingga, ada $m$ outputs, $n$ inputs, dan $j$ industri penangkapan ikan atau pengamatan. Input dibagi menjadi fixed inputs $\left(x_{f}\right)$ dan variabel inputs $\left(x_{v}\right)$.

2. Selanjutnya dihitung dengan menggunakan persamaan sebagai berikut (Färe et al.,1989):

$$
\underset{\theta, z, \lambda}{\operatorname{Max}} \theta_{1}
$$

Dengan kendala:

$$
\begin{array}{ll}
\theta_{1} u_{j m} \leq \sum_{j=1}^{J} z_{j} u_{j m}, & \mathrm{~m}=1,2, \ldots \ldots, \mathrm{m} \\
\sum_{j=1}^{J} z_{j} x_{j n} \leq x_{j n}, & n \in x_{f}
\end{array}
$$




$$
\begin{array}{ll}
\sum_{j=1}^{J} z_{j} x_{j n}=\lambda_{j n} x_{j n}, & n \in x_{v} \\
z_{j} \geq 0, & \mathrm{j}=1,2, \ldots \ldots, \mathrm{j} \\
\lambda_{j n} \geq 0, & n \in x_{v}
\end{array}
$$

di mana:

$z_{j} \quad=$ variabel intensitas untuk $j$ tahun pengamatan

$\theta_{1}=$ nilai efisiensi teknis atau proporsi di mana output dapat ditingkatkan pada kondisi produksi dengan tingkat kapasitas penuh

$\lambda_{j n}^{*}=$ rata-rata pemanfaatan variabel input (variable input utilization rate), yaitu rasio penggunaan inputan secara optimum $x_{j n}$ terhadap pemanfaatan input dari pengamatan $x_{j n}$

Kapasitas output pada efisiensi teknis (technical efficiency capacity output) kemudian didefinisikan dengan menggandakan $\theta_{1}^{*}$ menggunakan produksi sesungguhnya. Kapasitas pemanfaatan (capacity of utilization), berdasarkan pada output pengamatan, dihitung dengan persamaan berikut (Färe et al., 1989):

$$
T E C U=\frac{u}{\theta_{1}^{*} u}=\frac{1}{\theta_{1}^{*}}
$$

Metode perhitungan ini kemungkinan besar mengandung bias, karena pembilang dalam perhitungan capacity utilization, output pengamatan, dan tidak dihasilkan pada tingkat efisiensi teknis. Efisiensi teknologi dari output, pada level observasi, kemudian dapat ditentukan dengan memecahkan persoalan program linear lain (Färe et al., 1989):

$$
\operatorname{Max}_{\theta, z} \theta_{2}
$$

Dengan kendala:

$$
\begin{array}{ll}
\theta_{2} u_{j m} \leq \sum_{j=1}^{J} z_{j} u_{j m}, & \mathrm{~m}=1,2, \ldots \ldots, \mathrm{m} \\
\sum_{j=1}^{J} z_{j} x_{j n} \leq x_{j n}, & \mathrm{n}=1,2, \ldots, \mathrm{n} \\
z_{j} \geq 0, & \mathrm{j}=1,2, \ldots \ldots, \mathrm{j} \\
\lambda_{j n} \geq 0, & n \in x_{v}
\end{array}
$$

Efisiensi teknis kemudian diukur sebagai:

$$
T E=\frac{1}{\theta_{2}^{*}}
$$

Kapasitas pemanfaatan dalam kondisi efisiensi teknis yang tak bias kemudian dihitung sebagai:

$$
C U=\frac{\theta_{2}^{*} u}{\theta_{1}^{*} u}=\frac{\theta_{2}^{*}}{\theta_{1}^{*}}
$$

\section{HASIL DAN BAHASAN}

Dari hasil pengumpulan data di lapangan 106 kapal sebagai decision making unit tampak bahwa rata-rata nilai kapasitas penangkapan ( $C U$ ) adalah 0,43, sedangkan hasil perhitungan dari pemanfaatan variabel input (variable input utilization), menunjukkan bahwa variable input utilization 1 (daya lampu) mempunyai nilai rata-rata 1,04, maksimal 2,67, dan minimal 0,40. Nilai variable input utilization 2 (bahan bakar) mempunyai rata-rata 1,02, maksimal 11,10 dan minimal 0,10 . Sedangkan variable input utilization 3 (perbekalan) mempunyai rata-rata 0,80 , maksimal 1,50 dan minimal 0,10 (Tabel 1).

Menurut Smith \& Hanna (1990), efisiensi teknis kapal merupakan salah satu komponen dari 4 kapasitas armada kapal ikan. Tiga komponen lain yaitu jumlah kapal, ukuran tiap kapal, dan kemampuan waktu penangkapan tiap kapal pada tiap periode waktu (tahun atau musim).

Tabel 1 di atas terlihat bahwa nilai rata-rata kapasitas pemanfaatan (CU) dari 106 kapal sebagai decision making unit menunjukkan nilai 0,43 yang mengindikasikan pemanfaatan kurang optimum, di mana hasil perhitungan menunjukkan nilai tingkat kapasitas pemanfaatan optimum adalah 1.

Pada hasil perhitungan pemanfaatan variabel input (variable input utilization 1 dan 2) menunjukkan nilai rata-rata di atas 1 (optimum = 1) yang mengindikasikan adanya kelebihan penggunaan variabel sehingga dipandang perlu untuk melakukan pengurangan. Kebalikan dengan nilai variable input utilization 1 dan 2, pada variable input utilization 3 terlihat nilai rata-rata 0,80 yang mengindikasikan adanya kekurangan penggunaan variabel.

Menurut Pascoe et al. (2004), kapasitas berlebih (over capacity) dapat didefinisikan sebagai over capitalization manakala ukuran jangka panjangnya berdasarkan pada output yang dikaitkan dengan 
Tabel 1. Parameter efisiensi dari 106 kapal pukat cincin di Pemalang

Table1. Efficiency parameter from 106 purse seiners in Pemalang

\begin{tabular}{lcccc}
\hline \multicolumn{1}{c}{ Nilai hasil perhitungan/Calculated value } & CU & VIU1 & VIU2 & VIU3 \\
\hline Maksimum & 1,00 & 2,67 & 11,10 & 1,50 \\
Minimum & 0,01 & 0,40 & 0,10 & 0,10 \\
\hline Rata-rata & $\mathbf{0 , 4 3}$ & $\mathbf{1 , 0 4}$ & $\mathbf{1 , 0 2}$ & $\mathbf{0 , 8 0}$ \\
\hline
\end{tabular}

Keterangan/Remarks: Cu: kapasitas pemanfaatan; VIU 1: daya lampu; VIU 2: bahan baker; VIU 3: perbekalan

Distribution of Capacity Lilization

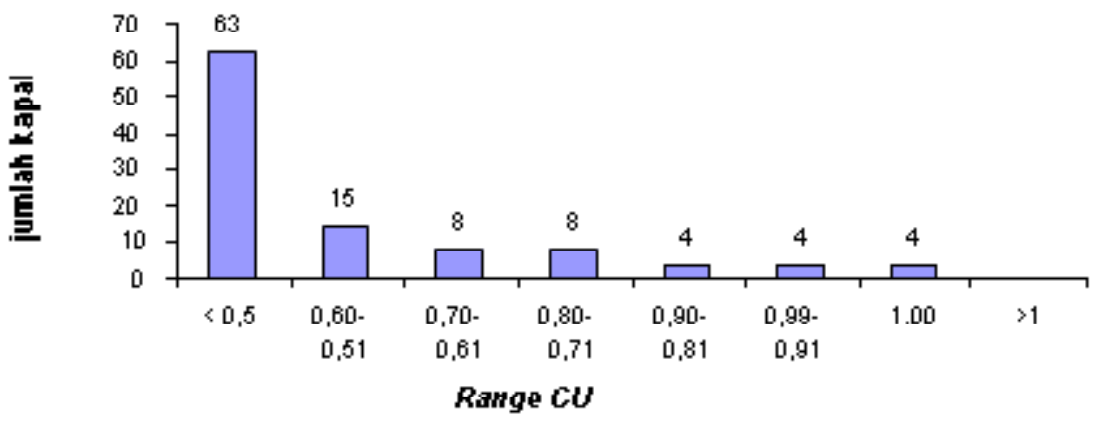

Gambar 1. Distribusi kapasitas pemanfaatan (CU).

Figure 1. Distribution of CU.

Distribution of Uaniable hput Chilization

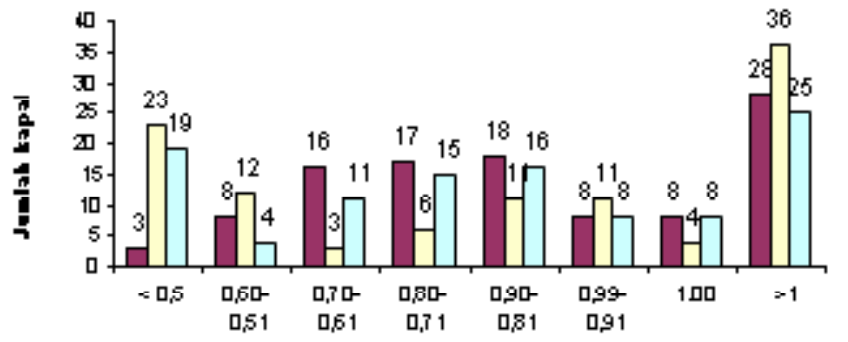

Range VN

口viu1 $\square$ viu2 $\square$ viu3

Gambar 2. Distribusi pemanfaatan variabel input (VIU).

Figure 2. Distribution of VIU.

jumlah armada saat ini untuk mencapai stok yang ditargetkan. Pada saat yang sama ukuran input-nya didasarkan pada tingkat investasi saat ini (dalam hal jumlah kapal, GT, dan satuan lain) pada tingkat investasi yang ditargetkan.

Gambar 1 dapat dilihat nilai $C U<0,5$ yaitu 63 kapal atau hampir mencapai $60 \%$. Hal ini menunjukkan bahwa nilai $C U$ kurang dari 1 mendominansi distribusi perolehan nilai $C U$ yang dapat diartikan telah terjadi kelebihan kapasitas pemanfaatan (over capacity).

Gambar 2 terlihat bahwa nilai VIU 1, 2, dan 3 sangat bervariasi yang didominansi dengan nilai $>1$, hal ini menunjukkan adanya kelebihan nilai variabel input yang dikurangi agar biaya operasional kapal dapat ditekan. Berdasarkan pada nilai VIU, gejala ini bukan disebabkan karena kurangnya input yang digunakan, tetapi lebih disebabkan oleh ketidakefisienan dalam penggunaan variabel input.

Penentuan acuan nilai efisiensi adalah yang memiliki nilai ambang batas skor efisiensi 1. Gambar 3 menunjukkan bahwa nilai skor efisiensi $C U$ tertinggi pada bulan Oktober dengan nilai 1,00, kemudian bulan Januari 0,96 , sedangkan terendah pada bulan Mei dengan skor efisiensi 0,36. Grafik fluktuasi angka efisiensi tersebut memperlihatkan bahwa perikanan pukat cincin mini di Pemalang sebagian besar tidak efisien. 


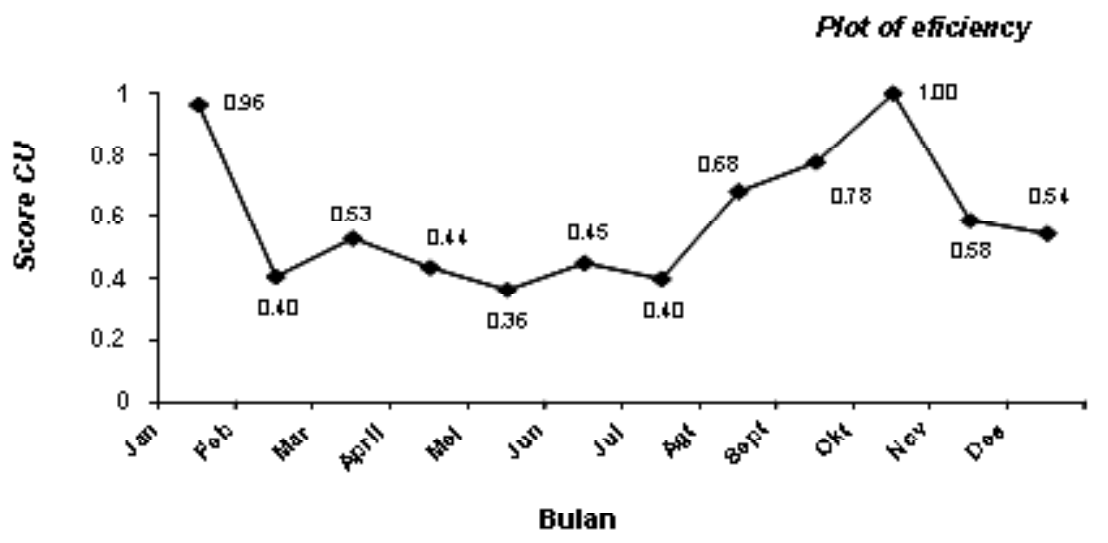

Gambar 3. Fluktuasi nilai efisiensi.

Figure 3. Fluctuation of efficiency value.

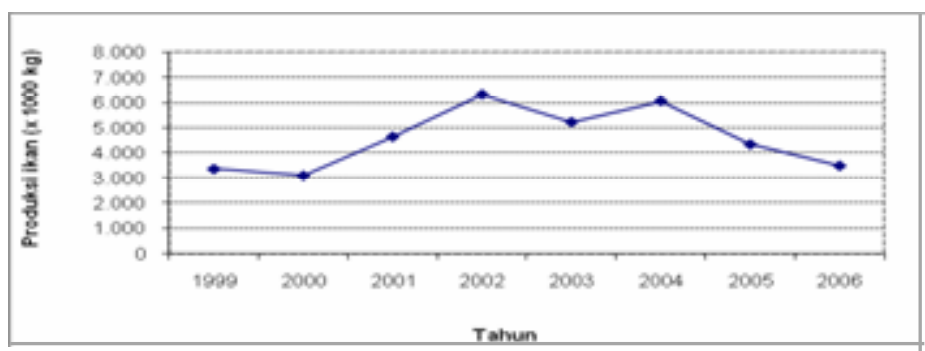

Gambar 4. Produksi hasil tangkapan purse seine di Pemalang.

Figure 4. Catch production of purse seine in Pemalang.

Bulan Oktober dijadikan acuan karena nilai efisiensinya 1 , sedangkan bulan lainnya diperbandingkan secara relatif terhadap bulan Oktober. Perbandingan relatif tingkat pemanfaatan kapasitas penangkapan ikan antar bulan pada lokasi penelitian menunjukkan bahwa tingkat pemanfaatan optimum hanya terjadi pada bulan Oktober dan Januari 0,96 yang mendekati optimum. Sementara pada bulanbulan yang lain menunjukkan tingkat pemanfaatan yang belum optimum.

Dari hasil tersebut dapat dikatakan bahwa telah terjadi kapasitas berlebih untuk penangkapan ikan menggunakan pukat cincin mini di Pemalang. Hal tersebut mengindikasikan bahwa ketersediaan stok ikan pada daerah tersebut memang sudah rendah.

Nilai produksi tahunan ikan hasil tangkapan pukat cincin di Kabupaten Pemalang mengalami fuktuasi (Gambar 4). Tahun 2002 dan 2004 merupakan produksi tertinggi. Produksi terendah terjadi pada tahun 2000. Tahun 2004 terus mengalami penurunan produksi sampai 2006. Hal ini dapat mengindikasikan bahwa keberadaan sumber daya perikanan mengalami penurunan dan usaha perikanan pukat cincin mini di Pemalang telah mencapai kondisi tangkap lebih (overfishing).
Waridin (2007) mengatakan bahwa produksi perikanan tangkap di Jawa Tengah tahun 2000-2004 baik volume maupun nilainya mengalami penurunan rata-rata 2,95 dan $4,74 \%$ per tahun. Hal ini sebagai salah satu indikasi bahwa kondisi perairan di pantai utara Jawa Tengah sudah dalam keadaan lebih tangkap.

\section{KESIMPULAN DAN SARAN}

\section{Kesimpulan}

1. Telah terjadi kapasitas berlebih (over capacity) terhadap kapasitas penangkapan mini purse seine di Pemalang dengan nilai rata-rata $C \cup 0,43$.

2. Nilai VIU 1 (daya lampu), VIU 2 (bahan bakar), dan VIU3 (perbekalan) didominansi dengan nilai $>1$, hal ini menunjukkan adanya kelebihan nilai variabel input.

\section{Saran}

1. Dengan melihat nilai teknis efisiensi bulanan, maka sebaiknya pengoperasian kapal pukat cincin mini dioptimalkan pada bulan Januari dan Oktober. 
2. Perlu adanya kontrol operasi penangkapan secara efektif melalui regulasi yang ketat oleh pemerintah.

\section{PERSANTUNAN}

Kegiatan dari hasil riset perikanan pukat cincin di perairan Laut Jawa, T. A. 2007, Balai Riset Perikanan Laut-Muara Baru, Jakarta.

\section{DAFTAR PUSTAKA}

Atmadja, S. B. 2002. Dinamika perikanan purse seine di Laut Jawa dan sekitarnya. Tesis Magister Sains. Program Studi Teknologi Kelautan. Sekolah Pascasarjana. Institut Pertanian Bogor. Bogor.

Food and Agriculture Organization of the United Nations 1995. Code of Conduct for Responsible Fisheries. Rome.

Färe, R., S. Grosskopf, \& J. Kirkley. 1989. Measuring plant capacity utilization and technical change: A non parametric approach. Int. Econ. Rev. 30: 655666.

Pascoe, S., D. Greboval, J. Kirkley, \& E. Lindebo. 2004. Measuring and appraising capacity in fisheries: Framework, analytical tools, and data aggregation. Rome: FAO Fisheries Circular No.994.

Smith, C. L. \& S. S. Hanna. 1990. Measuring fleet capacity and capacity utilization. Canadian Journal of Fisheries and Aquatic Science. 47 pp.

Sularso, A. 2005. Alternatif pengelolaan perikanan udang di Laut Arafura. Disertasi Program Doktor. Institut Pertanian Bogor. Bogor.

Waridin. 2007. Beberapa faktor yang mempengaruhi partisipasi nelayan dalam pembangunan komunitas di tempat pendaratan ikan Asemdoyong, Kabupaten Pemalang, Jawa Tengah. Jurnal Ekonomi Pembangunan. Fakultas Ekonomi Universitas Muhamadiyah Surakarta. 8 (1): 85-95.

Wiyono, E. S. \& R. I. Wahju. 2006. Perhitungan kapasitas penangkapan (fishing capacity) pada perikanan skala kecil pantai: Suatu penelitian pendahuluan. Prosiding Seminar Nasional Perikanan Tangkap. Fakultas Perikanan dan IImu Kelautan. Institut Pertanian Bogor. p. 381-389. 
Lampiran 1. Data efisiensi dari 106 kapal purse seine Pemalang Apenddix 1. Efficience data of 106 purse seine in Pemalang

\begin{tabular}{|c|c|c|c|c|c|}
\hline No. & Nama kapal & CU & VIU1 & VIU2 & VIU3 \\
\hline 1. & Alam Jaya & 0,95 & 0,83 & 0,98 & 0,83 \\
\hline 2. & Alam Jaya II & 0,58 & 1,56 & 0,60 & 0,67 \\
\hline 3. & Alur & 0,12 & 1,00 & 0,39 & 0,79 \\
\hline 4. & Amalia & 0,31 & 0,82 & 0,83 & 0,94 \\
\hline 5. & Aman Jaya & 0,58 & 2,20 & 0,89 & 0,68 \\
\hline 6. & Armadina 1 & 0,25 & 0,76 & 0,64 & 0,71 \\
\hline 7. & Armadina 2 & 0,18 & 0,92 & 0,25 & 0,48 \\
\hline 8. & Armadina 3 & 0,23 & 0,71 & 0,15 & 0,14 \\
\hline 9. & Arto Moro & 0,65 & 0,60 & 2,08 & 0,10 \\
\hline 10. & Astra & 0,97 & 0,44 & 0,56 & 0,74 \\
\hline 11. & Bahari & 0,73 & 2,4 & 1,03 & 0,80 \\
\hline 12. & Bahrun Mubarok & 0,56 & 0,88 & 0,97 & 0,94 \\
\hline 13. & Bahrtera Anugerah & 0,89 & 0,61 & 11,10 & 0,87 \\
\hline 14. & Bahtera Laju & 0,59 & 0,60 & 0,90 & 1,02 \\
\hline 15. & Baras Pusaka & 0,59 & 0,53 & 1,05 & 1,06 \\
\hline 16. & Baru Muncul & 0,32 & 2,10 & 1,08 & 1,11 \\
\hline 17. & Baruna & 0,37 & 0,86 & 0,84 & 1,27 \\
\hline 18. & Bintang Kejora & 1,00 & 1,00 & 1,00 & 1,00 \\
\hline 19. & Bintang Mas Berlian & 0,70 & 0,73 & 0,99 & 0,95 \\
\hline 20. & Bintang Mas Makmur & 0,80 & 1,00 & 2,08 & 0,10 \\
\hline 21. & Bintang Mas Mentari & 0,52 & 0,78 & 1,09 & 1,03 \\
\hline 22. & Bintang Mas cahaya & 0,50 & 0,80 & 0,71 & 0,67 \\
\hline 23. & Bintang Mas Pusaka & 0,90 & 0,87 & 0,86 & 0,79 \\
\hline 24. & Bintang Mas Terang & 0,85 & 0,98 & 1,02 & 0,69 \\
\hline 25. & Br. Pojok & 0,03 & 2,12 & 2,09 & 0,39 \\
\hline 26. & Bunga Indah & 0,04 & 1,00 & 0,94 & 0,94 \\
\hline 27. & Citra Jaya & 0,47 & 1,05 & 0,37 & 0,58 \\
\hline 28. & Dewi Ayu & 0,23 & 1,81 & 2,08 & 0,27 \\
\hline 29. & Duryat & 0,10 & 2,14 & 0,12 & 0,60 \\
\hline 30. & Elang Jaya & 0,54 & 0,65 & 0,82 & 0,69 \\
\hline 31. & Elang Raja & 0,79 & 0,62 & 0,95 & 0,92 \\
\hline 32. & Elang Raja II & 0,73 & 1,33 & 0,60 & 1,17 \\
\hline 33. & Elang Sakti & 0,50 & 0,67 & 1,14 & 0,83 \\
\hline 34. & Erik mly & 0,52 & 0,67 & 1,05 & 1,00 \\
\hline 35. & Gesang & 0,42 & 1,00 & 0,39 & 0,83 \\
\hline 36. & H. Dari 1 & 0,32 & 0,41 & 0,29 & 0,77 \\
\hline 37. & H. Dari 2 & 0,47 & 0,40 & 0,38 & 0,49 \\
\hline 38. & H. Dari 3 & 0,85 & 1,18 & 0,56 & 0,59 \\
\hline 39. & H. M. Dahril & 0,26 & 0,82 & 0,88 & 1,02 \\
\hline 40. & Hasil Kota & 0,21 & 0,70 & 0,57 & 0,87 \\
\hline 41. & Hasil Laut & 0,59 & 0,65 & 0,82 & 0,83 \\
\hline 42. & Indra Jaya & 0,03 & 2,30 & 0,45 & 0,15 \\
\hline 43. & Jaya Utama & 0,01 & 1,57 & 2,06 & 0,10 \\
\hline 44. & Jujur Jaya & 0,18 & 0,63 & 0,58 & 0,94 \\
\hline 45. & Karisma & 0,75 & 0,70 & 0,29 & 0,50 \\
\hline 46. & Kartika Jaya & 0,21 & 2,38 & 0,58 & 0,77 \\
\hline 47. & Karunia & 0,07 & 0,83 & 0,96 & 0,81 \\
\hline 48. & Kasi II & 0,14 & 0,55 & 0,40 & 1,21 \\
\hline 49. & KDI & 0,01 & 1,57 & 2,07 & 0,12 \\
\hline 50. & Kenalan Indah & 0,16 & 0,92 & 0,68 & 0,81 \\
\hline 51. & Kharisma & 0,18 & 0,87 & 2,08 & 0,67 \\
\hline 52. & Kiswan & 0,44 & 0,51 & 0,73 & 0,89 \\
\hline
\end{tabular}


Lanjutan Lampiran 1. Data efisiensi dari 106

Continued Apenddix 1. Efficience data of 106

\begin{tabular}{|c|c|c|c|c|c|}
\hline No. & Nama kapal & $\mathrm{CU}$ & VIU1 & VIU2 & VIU3 \\
\hline 53. & $\mathrm{KNI} \mathrm{I}$ & 0,61 & 1,26 & 1,89 & 1,12 \\
\hline 54. & KNI II & 0,36 & 0,68 & 1,08 & 0,96 \\
\hline 55. & Kondang In & 0,09 & 1,00 & 0,10 & 0,10 \\
\hline 56. & Kota Baru & 0,48 & 0,70 & 0,41 & 1,03 \\
\hline 57. & Kota Santri & 0,26 & 1,13 & 0,40 & 1,01 \\
\hline 58. & Maju Jaya & 0,09 & 0,77 & 0,97 & 0,79 \\
\hline 59. & Mayang Sari & 0,01 & 1,88 & 2,09 & 0,15 \\
\hline 60. & Minta Lestari & 0,05 & 1,32 & 0,53 & 0,47 \\
\hline 61. & Miranda & 0,03 & 1,00 & 2,08 & 0,37 \\
\hline 62. & Mitra Bahari & 0,72 & 0,78 & 0,96 & 0,89 \\
\hline 63. & Muara & 0,26 & 0,82 & 0,88 & 1,02 \\
\hline 64. & Mutiara I & 0,61 & 0,59 & 0,30 & 0,89 \\
\hline 65. & Mutiara II & 0,65 & 0,74 & 1,39 & 0,89 \\
\hline 66. & NA & 0,53 & 0,75 & 1,14 & 1,01 \\
\hline 67. & Ndari & 1,00 & 1,00 & 1,00 & 1,00 \\
\hline 68. & Nogorejo & 0,59 & 0,73 & 1,04 & 1,04 \\
\hline 69. & NS & 0,67 & 1,33 & 0,60 & 1,00 \\
\hline 70. & Nuril Anwar & 0,35 & 0,60 & 1,03 & 1,00 \\
\hline 71. & Pupon & 0,16 & 1,18 & 2,04 & 0,63 \\
\hline 72. & Putra Jaya & 0,25 & 0,79 & 1,05 & 0,70 \\
\hline 73. & Putra Kencana & 0,19 & 2,38 & 0,58 & 0,77 \\
\hline 74. & Putra Kontan & 0,14 & 0,82 & 0,73 & 0,77 \\
\hline 75. & Rahayu & 0,16 & 2,44 & 0,80 & 1,02 \\
\hline 76. & Restu B & 0,09 & 0,86 & 1,60 & 1,50 \\
\hline 77. & Riris & 0,15 & 0,72 & 1,54 & 1,15 \\
\hline 78. & Rudy Jaya & 0,48 & 0,70 & 0,35 & 0,90 \\
\hline 79. & Sami Jaya & 0,23 & 0,72 & 0,66 & 1,02 \\
\hline 80. & Sami Jaya II & 1,00 & 0,66 & 0,72 & 0,15 \\
\hline 81. & Sanjaya & 0,59 & 1,08 & 1,00 & 0,80 \\
\hline 82. & Sari Timbul & 0,47 & 0,90 & 0,82 & 1,30 \\
\hline 83. & Setia Makmur & 0,42 & 2,38 & 1,03 & 0,80 \\
\hline 84. & Sinar Abadi & 0,63 & 0,88 & 0,79 & 0,76 \\
\hline 85. & Sinar Mutiara & 0,77 & 0,86 & 1,00 & 0,83 \\
\hline 86. & Sinar Ultra & 0,52 & 1,05 & 0,88 & 0,83 \\
\hline 87. & Sri Ganti & 0,69 & 0,93 & 0,49 & 1,18 \\
\hline 88. & Sri Rejeki & 0,12 & 2,46 & 2.08 & 0,67 \\
\hline 89. & Sri Wulan 1 & 0,34 & 0,80 & 0,27 & 0,40 \\
\hline 90. & Sri Wulan 2 & 0,15 & 0,72 & 0,12 & 0,16 \\
\hline 91. & Sukeri & 0,36 & 0,71 & 0,12 & 0,75 \\
\hline 92. & Sumber Rizqi & 0,23 & 2,67 & 2,67 & 1,33 \\
\hline 93. & Timbul & 0,15 & 0,86 & 1,20 & 1,00 \\
\hline 94. & Timbul Baru & 0,95 & 0,69 & 0,23 & 0,62 \\
\hline 95. & Valencia & 0,46 & 0,94 & 0,99 & 0,93 \\
\hline 96. & Wahroni 1 & 0,42 & 0,53 & 0,57 & 1,33 \\
\hline 97. & Wanito & 0,01 & 1,33 & 1,25 & 1,00 \\
\hline 98. & Warman & 0,56 & 0,83 & 0,11 & 1,33 \\
\hline 99. & Warung Kota & 0,16 & 0,93 & 0,96 & 0,79 \\
\hline 100. & Wijaya & 0,04 & 2,41 & 1,60 & 1,50 \\
\hline 101. & Wilujeng & 0,45 & 0,78 & 1,03 & 0,70 \\
\hline 102. & Wiroso & 0,55 & 0,69 & 0,32 & 0,30 \\
\hline 103. & WR kenalan & 1,00 & 0,67 & 1,05 & 1,00 \\
\hline 104. & Wr Pojok & 0,12 & 0,86 & 1,60 & 1,50 \\
\hline 105. & Yosinaga & 0,94 & 0,92 & 0,94 & 0,88 \\
\hline 106. & Ziaroh & 0,80 & 0,97 & 0,54 & 0,54 \\
\hline \multicolumn{2}{|r|}{ Max } & 1,00 & 2,67 & 11,10 & 1,50 \\
\hline \multicolumn{2}{|r|}{ Min } & 0,01 & 0,40 & 0,10 & 0,10 \\
\hline \multicolumn{2}{|r|}{ Average } & 0,43 & 1,04 & 1,02 & 0,80 \\
\hline
\end{tabular}




\title{
PEMANCARAN SINYAL AKUSTIK BUATAN UNTUK MERESPON TINGKAH LAKU IKAN BANDENG (Channos sp.) PADA SKALA PERCOBAAN
}

\author{
Agus Cahyadi \\ Peneliti pada Pusat Riset Teknologi Kelautan, Ancol-Jakarta \\ Teregistrasi I tanggal: 1 Juli 2008; Diterima setelah perbaikan tanggal: 2 Maret 2009; \\ Disetujui terbit tanggal: 16 April 2009
}

\begin{abstract}
ABSTRAK
Salah satu fungsi gurat sisi pada ikan adalah mendeteksi gerakan antar sesama ikan yang diakibatkan oleh faktor lingkungan maupun fisiologi ikan. Tujuan penelitian ini adalah merespon tingkah laku sekumpulan ikan bandeng terhadap sinyal akustik buatan atau SAB. SAB merupakan sinyal yang dibangkitkan dari perubahan fase akustik sebagai nilai perbedaan waktu tunda (delay) yang terjadi pada saat ikan bergerak secara fluktuatif. Melalui penelitian eksperimen, SAB diujicobakan pada skala percobaan dengan mengaktifasi SAB pada perioda $0.01-0.19$ detik dan amplituda-nya adalah $34.6 \mathrm{~dB}$. Pengujian statistik dilakukan untuk dua variabel, yaitu intensitas akustik kuat dan intensitas akustik normal. SAB pada intensitas akustik kuat menunjukan respon yang agresif terhadap tingkah laku kumpulan ikan bandeng pada skala percobaan.
\end{abstract}

KATAKUNCI: $\quad$ sinyal akustik buatan, bandeng, Channos sp, skala percobaan

ABSTRACT: Acoustic of phase shifted activation to respond the milk fish (Channos sp.) behavior at experimental scale, By: Agus Cahyadi

One of linea lateralis function of fish is to detect the motion among fishes which caused by environment factor or fish physiology. The goal research is to respond the schooling fish behavior that artificial acoustic signal or SAB. SAB generated from shifted phase acoustic is delayed time occur at fish swims fluctuate. $S A B$ is tested on experimental scale with activating $S A B$ at 0.01 to 0.19 periods and its amplitude is $34.6 \mathrm{~dB}$. Statistic test is conducted for two variables, namely peak and normal intensity of acoustic. They are peak acoustic intensity and normal acoustic intensity. SAB at peak acoustic intensity showed aggressive respond to milkfish schooling behavior on experimental scale.

KEYWORDS: $\quad$ artificial acoustic signal, milk fishes, Channos sp., experimental scale

\section{PENDAHULUAN}

Fish schooling atau sekumpulan ikan didefinisikan sebagai gerakkan ikan yang berenang secara terpolarisasi dan sinkronisasi (Webb et al., 2008). Pada umumnya sekumpulan ikan yang bergerak pada malam hari membentuk formasi menyebar, memperluas bentuk, dan membatasi kumpulan. Fungsi dari fish schooling adalah untuk menghindari serangan predator, mencari makan yang efektif, keuntungan dalam hidrodinamik, migrasi (migration), reproduksi, dan pembelajaran. Semakin panjang ikannya, maka semakin kecil kepadatannya (Picher \& Partridge, 1979). Kepadatan schooling ikan dalam jumlah ikan per unit volume tergantung dari jenis dan panjang ikan (Partridge, 1981).

Pergerakkan sekumpulan ikan dapat dideteksi oleh teknologi instrumen pembangkit perubahan fase akustik (Diponegoro, 2006) yang merupakan modifikasi instrumentasi sistem komunikasi dengan sistem akustik dual beam (Medwin \& Clarence, 1994). Sistem komunikasi seperti radio maupun pemancar yang berkembang saat ini menerapkan teknik perubahan fase (Kukushkin, 2004). Teknik ini memindai gejala pantulan yang dihasilkan oleh suatu obyek yang bergerak, contohnya gerakkan pohon, pergerakkan bangunan, dan lain-lain. Hal yang sama juga dapat diaplikasikan untuk memindai pergerakkan sekumpulan ikan yang berenang di air. Melalui teknologi perubahan fase akustik, fluktuasi sinyal informasi secara tidak teratur merupakan representasi dari profil atau permukaan pantulan dari ikan tersebut. Semakin cepat gerakkan ikan, semakin cepat fluktuasi yang terjadi. Perubahan fase akustik merupakan bahan dasar untuk diaplikasikan pada sistem liukan ikan (Cahyadi, 2004) sebagai sinyal akustik buatan.

Sinyal ini yang diuji cobakan pada sekumpulan ikan bandeng (Channos sp.) sebagai sasaran akustik. Oleh sebab itu, tujuan dari penelitian ini adalah untuk mengetahui respons tingkah laku sekumpulan ikan bandeng terhadap sinyal akustik buatan yang dibangkitkan oleh sistem liukan ikan. 